\title{
Estimation of Cranial Capacity and Growth Indicators in Elementary School Children
}

\author{
Estimación de Capacidad Craneal e Indicadores de Crecimiento en Niños de Educación Primaria
}

Viskasari P. Kalanjati

KALANJATI, V. P. Estimation of cranial capacity and growth indicators in elementary school children. Int. J. Morphol., 32(1):7-11, 2014.

SUMMARY: Cranial capacity (CC) can be used to estimate the brain volume and is correlated to the growth and development in children. Anthropometry is a useful method to obtain data of estimated cranial capacity and other growth indicators including body weight (BW) and body height (BH). Neuromuscular reflex test (NMRT) is a method to observe children's neuromuscular function. The aim of this study is to elucidate and to understand correlation between estimated CC, BW, BH, body mass index (BMI) and neuromuscular function in elementary school children in East Java, Indonesia age 7-14 years old. The anthropometric study was carried out in 153 boys and 145 girls from 3 elementary schools in East Java age 7-14 years old to measure BH and BW to calculate the BMI by WHO formula. Other data taken including NMRT and maximum head length, maximum head breadth between parietal eminence, and head height from vertex to tragus; last three are to calculate the estimated CC using formula of Manjunath (2002a). Correlations between CC, BW, BH, BMI and NMRT were analyzed with Microsoft Excel. For comparison of cranial capacity means between boys and girls, two-tailed t test was done ( $\mathrm{p}>0.05$ ). In boys, a positive correlation was found between the CC and: BMI ( $r=0.38), \mathrm{BW}(\mathrm{r}=0.4), \mathrm{BH}(\mathrm{r}=0.3)$; whilst no obvious correlation was observed between the CC and NMRT ( $\mathrm{r}=0.07)$. In girls, a positive correlation was found between the CC and: BMI ( $\mathrm{r}=0.33)$, BW ( $\mathrm{r}=0.45)$, BH ( $\mathrm{r}=0.48)$; whilst negative correlation was observed between the CC and NMRT ( $\mathrm{r}=-0.05)$. Results indicate there is a strong linier correlation between $\mathrm{CC}$ and $\mathrm{BMI}$, and $\mathrm{BW}$, and $\mathrm{BH}$ in both boys and girls. No obvious correlations were found between CC and NMRT in boys and girls.

KEY WORDS: Craniometry; Morphology; Human development.

\section{INTRODUCTION}

Estimated cranial capacity can be obtained either from the cadaver or human (Wolf et al., 2003). Several methods to estimate the cranial capacity were reported in previous literatures, including by imaging i.e. magnetic resonance imaging (MRI), computed tomography (CT) scan and by craniometry (Acer et al., 2007). Whilst others reported that the volume of water filled in the balloon inside of a skull is a reliable standard procedure to estimate cranial capacity in the cadaver (Dekaban, 1977; MacKinnon et al., 1955).

Although previous research reported that cranial capacity can be a good indicator for brain volume and intellectual potency, others showed that these are more to correlate to the actual microarchitecture of the brain and cellular and biomolecular functions i.e. integrating neurons, glials, neurotransmitters and the receptors as the synaps skeleton (Witelson et al., 2006). It has been reported that the physiological ratio between neurons and glials, spatiotemporal expressions of these cells and the synaps skeleton have more impact on determining cognitive and intellectual capacity (Johnson, 1991; Witelson et al.).

Limited data are available on the estimated cranial capacity of the school children. Furthermore, reports on its correlation to other growth and development indicators including body mass index (BMI), body weight, body height and to the neuromuscular function are scarce. These data is unquestionably has an important value to understand to detect any pathology on children's head growth and shape, to elucidate the state of children growth and development, to early identify any potential problems and to help deciding the policy to solve these. 


\section{MATERIAL AND METHOD}

One hundred fifty-three boys and 145 girls age 7-14 years old from Pacar Keling Elementary School, Tenggor Elementary School and Doho Agung Elementary School of 2 different cities, Surabaya and Gresik in East Java, Indonesia were involved in the current research. The ethical clearance to conduct the research is from the Committee of Medical Research Ethics, Faculty of Medicine, Universitas Airlangga, Surabaya, Indonesia (ethical clearance No.055/EC/KEPK/ FKUA/2011). The parents and teachers of these students were satisfactorily consented and signed both the form of informed consent and consent of information thus current research to be done.

Age was calculated from child's birthday. Body weight $(\mathrm{kg})$ was measured using digital balance (Camry, China), and body height $(\mathrm{cm})$ was measured by the anthropometry to calculate the body mass index or BMI $(\mathrm{kg} /$ $\mathrm{m}^{2}$ ) was then calculated and plotted against the World Health Organization (WHO) classification system (Report of a WHO consultation, 2000).

The craniometry was done to obtain the maximum head length ( $\mathrm{L}$ in $\mathrm{mm}$, glabella-inion length), the maximum head breadth (W in $\mathrm{mm}$, measured between parietal eminences) and the height between the highest point of vertex and the external acoustic meatus ( $\mathrm{H}$ in $\mathrm{mm}$ ). These measurements $(\mathrm{WxHxL}$, in $\mathrm{cm}$ ) were used to calculate the estimation of cranial capacity $\left(\mathrm{CC}\right.$, in $\left.\mathrm{cm}^{3}\right)$ using the formula of Manjunath (2000a). below:

The formula is different for boy and girl as noted

Boys: 0.000337(L-11) (W-11) (H-11) +406.01

Girls: 0.000400(L-11) (W-11) (H-11) +206.60.

Neuromuscular reflex test (NMRT) was done by measuring the length of the ruler $(\mathrm{cm})$ that was successfully stopped by a dominant thumb against the wall in a straight line in front of a standing child. Each measurement was repeated at least three times and the average of two closest results were considered for computation.

All measurements were conducted by well trained examiners according to a standardized protocol. All data were recorded and the interaction between the $\mathrm{CC}$ and other variables (BMI, NMRT, Body weight (BW), Body height (BH)) were analyzed by plotting at the XY scatter graphs and regression lines showed using Microsoft Excel 2007 to obtain the degree of correlation between these two variables. Differences between cranial capacity means in boys and girls were analyzed using student $t$-test $(\mathrm{p}<0.05)$.

\section{RESULTS}

Various parameters were shown for both sexes at Tables I and II below. Means ( \pm SD) of the cranial capacity of boys is $1248.32 \pm 155.19$ (range: $884.70-1537.81$ ), and of girls is $1160.72 \pm 148.21$ (range: $878.22-1593.48$ ). Boys CC was larger significantly to girls $(\mathrm{p}<0.000)$.

In boys, a positive correlation was found between the $\mathrm{CC}$ and BMI $(\mathrm{r}=0.38)$, between $\mathrm{CC}$ and body weight $(\mathrm{r}=0.4)$, between $\mathrm{CC}$ and body height $(\mathrm{r}=0.3)$; whilst no obvious correlation was observed between the $\mathrm{CC}$ and NMRT ( $r=0.07)$. In girls, a positive correlation was found between the $\mathrm{CC}$ and BMI ( $\mathrm{r}=0.33$ ), between $\mathrm{CC}$ and body weight ( $\mathrm{r}=0.45)$, between $\mathrm{CC}$ and body height $(\mathrm{r}=0.48)$; whilst negative correlation was observed between the $\mathrm{CC}$ and NMRT ( $\mathrm{r}=-0.05)$. The XY scatter graphs and regression lines of CC and BMI for boys and for girls, of CC and body weight for boys and for girls, of CC and body height for boys and for girls, of CC and NMRT for boys and for girls were depicted at Figures 1A and B to $4 \mathrm{~A}$ and B, respectively.

Table I. Various parameters on 153 boys 7-14 years old.

\begin{tabular}{lcccccccc}
\hline Boys & $\begin{array}{c}\text { BMI } \\
(\mathbf{k g} / \mathbf{m})\end{array}$ & $\begin{array}{c}\text { Body } \\
\text { Weight }(\mathbf{k g})\end{array}$ & $\begin{array}{c}\text { Body } \\
\text { Height }(\mathbf{c m})\end{array}$ & $\begin{array}{c}\text { NMRT } \\
(\mathbf{c m})\end{array}$ & $\begin{array}{c}\text { W } \\
(\mathbf{c m})\end{array}$ & $\begin{array}{c}\text { L } \\
(\mathbf{c m})\end{array}$ & $\begin{array}{c}\text { H } \\
(\mathbf{c m})\end{array}$ & $\begin{array}{c}\text { Cranial } \\
\text { Capacity }(\mathbf{c m} 3)\end{array}$ \\
\hline Mean & 17.03 & 28.02 & 127.28 & 39.92 & 145.19 & 166.01 & 132.14 & 1255.75 \\
SD & 3.70 & 8.42 & 8.09 & 19.93 & 9.84 & 7.20 & 12.37 & 118.69 \\
Minimum & 12.49 & 15.90 & 103.80 & 10.00 & 116.00 & 147.00 & 78.00 & 884.70 \\
Maximum & 34.36 & 55.10 & 156.60 & 83.45 & 167.00 & 187.00 & 172.00 & 1537.81 \\
\hline
\end{tabular}


Table II. Various parameters on 145 girls 7-14 years old.

\begin{tabular}{lcccccccc}
\hline Girls & $\begin{array}{c}\text { BMI } \\
\left(\mathbf{k g} / \mathbf{m}^{\mathbf{2}}\right)\end{array}$ & $\begin{array}{c}\text { Body Weight } \\
(\mathbf{k g})\end{array}$ & $\begin{array}{c}\text { Body Height } \\
(\mathbf{c m})\end{array}$ & $\begin{array}{c}\text { NMRT } \\
(\mathbf{c m})\end{array}$ & $\begin{array}{c}\text { W } \\
(\mathbf{c m})\end{array}$ & $\begin{array}{c}\text { L } \\
(\mathbf{c m})\end{array}$ & $\begin{array}{c}\text { H } \\
(\mathbf{c m})\end{array}$ & $\begin{array}{c}\text { Cranial } \\
\mathbf{C a p a c i t y ~}(\mathbf{c m})\end{array}$ \\
\hline Mean & 16.86 & 27.44 & 126.31 & 41.47 & 142.50 & 162.30 & 130.52 & 1160.72 \\
SD & 3.54 & 8.83 & 8.97 & 16.39 & 10.41 & 6.92 & 11.23 & 148.21 \\
Minimum & 11.90 & 16.20 & 106.10 & 7.00 & 110.00 & 143.00 & 103.00 & 878.22 \\
Maximum & 32.81 & 65.70 & 151.30 & 73.85 & 161.00 & 182.00 & 162.00 & 1593.48 \\
\hline
\end{tabular}
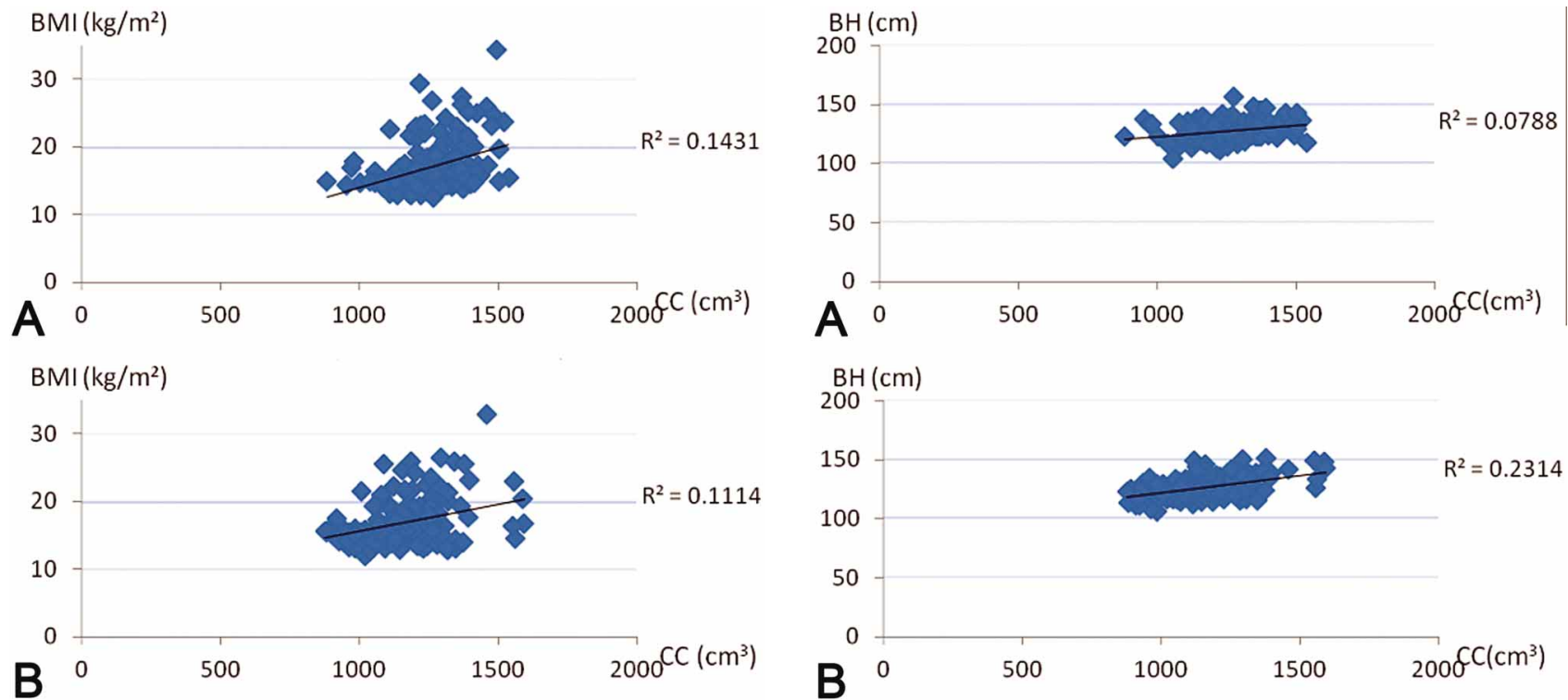

Fig. 1. A) Cranial capacity and BMI in girls, and B) in boys. The XY scatter graphs and regression lines of CC and BMI for boys ( $\mathrm{r}=0.38)$ and for girls $(\mathrm{r}=0.33)$, respectively. Positive correlations were observed between CC and BMI in both boys and girls.
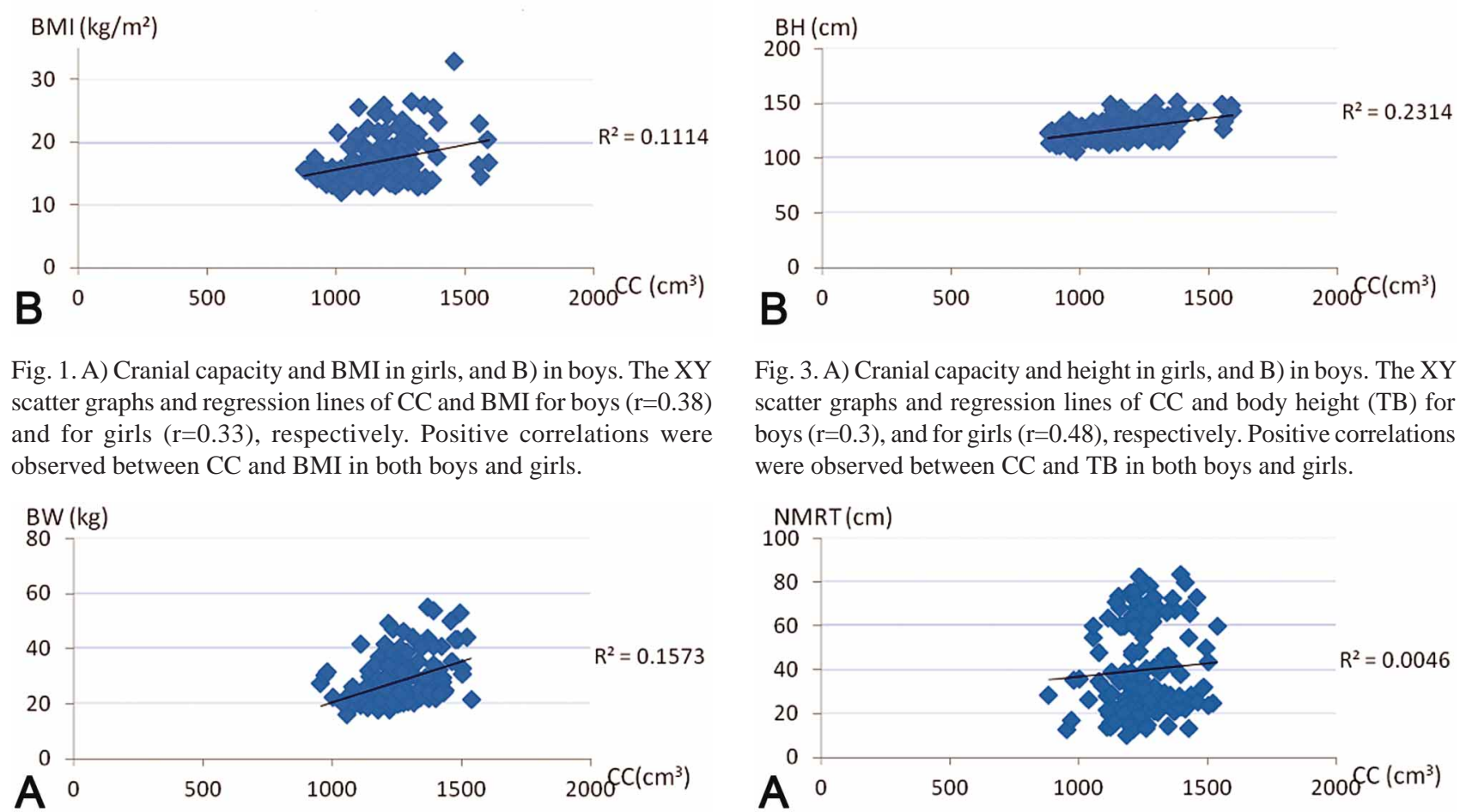

Fig. 3. A) Cranial capacity and height in girls, and B) in boys. The XY scatter graphs and regression lines of $\mathrm{CC}$ and body height (TB) for boys $(\mathrm{r}=0.3)$, and for girls $(\mathrm{r}=0.48)$, respectively. Positive correlations were observed between $\mathrm{CC}$ and TB in both boys and girls.

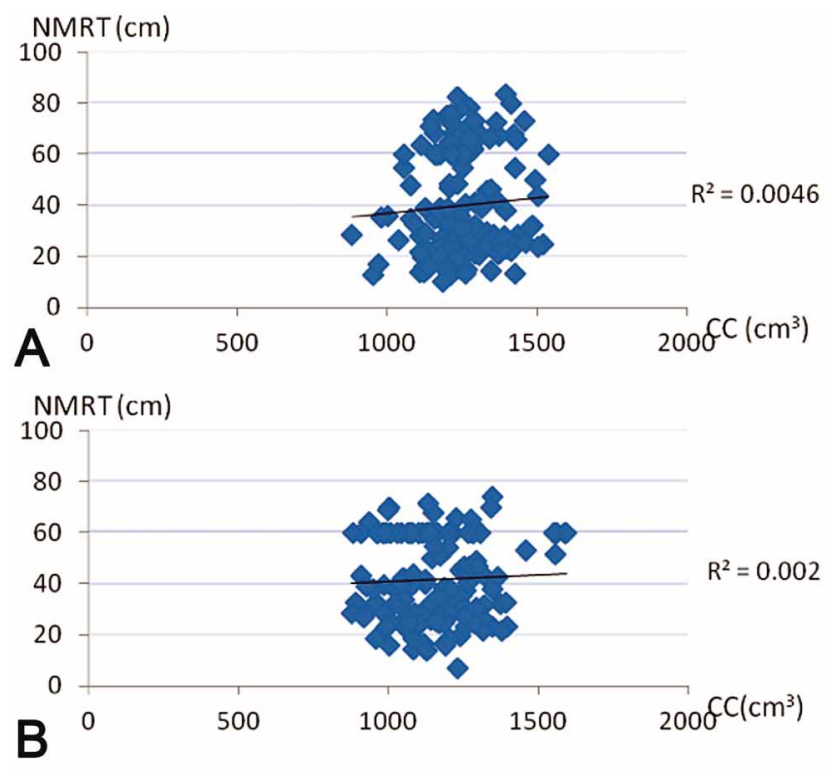

Fig. 2. A) Cranial capacity and body weight in girls, and B) in boys. The XY scatter graphs and regression lines of $\mathrm{CC}$ and body weight (BW) for boys $(\mathrm{r}=0.4)$, and for girls $(\mathrm{r}=0.45)$, respectively. Positive correlations were observed between $\mathrm{CC}$ and $\mathrm{BW}$ in both boys and girls.

Fig. 4. A) Cranial capacity and NMRT in girls, and B) in boys. The XY scatter graphs and regression lines of CC and NMRT for boys ( $\mathrm{r}=0.07)$, and for girls $(\mathrm{r}=-0.05)$, respectively. No obvious correlations were observed between CC and NMRT in both boys and girls. 


\section{DISCUSSION}

Cranial capacity of various races and ages have been reported previously. These used measurements whether from cadaver or living human (Acer et al.; Manjunath, 2002b; Sgouros et al., 1999; Wolf et al.). Several factors may affect the cranial capacity including growth and development and body maturation (Acer et al.; Manjunath, 2002b).

Dekaban reported that the cranial volume of 7 days to 29 years old in males is $1548 \mathrm{~cm}^{3}$, whilst in females is $1425 \mathrm{~cm}^{3}$. In the current research, boys cranial capacity mean was significantly larger than girls $\left(1248.32 \pm 155.19 \mathrm{~cm}^{3}\right.$, range: $884.70-1537.81 \mathrm{~cm}^{3}$; girls is $1160.72 \pm 148.21 \mathrm{~cm}^{3}$, range: $878.22-1593.48 \mathrm{~cm}^{3}$, respectively). These are smaller when compared to previous studies conducted in adults. In Acer et al., study on Turkey's University students, the males cranial capacity mean is $1375.67 \pm 91.17 \mathrm{~cm}^{3}$ whilst in females is $1237.32 \pm 95.12 \mathrm{~cm}^{3}$. Whilst Hwang et al. (1995), reported that the adult Korean's cranial volume mean in male skull is $1470 \pm 107 \mathrm{~cm}^{3}$, and in females is $1317 \pm 117$ $\mathrm{cm}^{3}$.

In boys and girls, cranial capacity is larger as maturation occurred. This is nicely observed in previous study by Sgouros et al. The growth of skull is closely correlated to the volume of cranium, especially in children under 5 years old, whereas the relatively stagnant volume is reached at age 16-20 years old (Piatt \& Arguelles, 1991; Sgouros et al.).

In the current research, cranial capacity is strongly correlated to BMI, body weight and body height, either in boys or in girls. These are similar to what Acer et al., observed in Turkey's University students, although there are differences in race and age.

Cranial capacity is one of the indicators to estimate brain volume (Gault et al., 1988; Wolf et al.). It was reported that the BMI is a prominent variable on the brain volume's growth (Ward et al., 2005). However, correlation between brain volume and cranial capacity and BMI in the current study has yet elucidated. Additional methods including brain imaging will be beneficial and is a limitation in the current study. In previous study, brain volume could be estimated by CT scan of the head (Gault et al.; Pearl, 1995; Mazonakis et al., 2004).

It was reported that there is a close correlation between the CT scan results with the intellectual levels in human (Witelson et al.). However, the potential intelligence might be more determined by the quality of the brain's component and other factors such as the growth environment. In the current study, the neuromuscular function was tested by doing the NMRT test. Interestingly, weak correlations were observed between the NMRT and the cranial capacity in boys and in girls. It is too premature to conclude that there is no correlation between these two parameters; bigger sample size might change the results. Other factors also may affect these results including fatigue and other stress sources, as this study was done lastly.

From this study, a preliminary data on school children's cranial capacity, NMRT, BMI, body weight and body height were obtained. Although no macroscopic head and body morphology anomaly was found, data from current study are vital for the authority, parents and teachers to grasp the idea on the current general health state of the children and to decide preventive methods of morbidity related to the abnormal growth and development in later life including type 2 diabetes mellitus.

\section{CONCLUSIONS}

The larger the cranial capacity of the school children, the bigger the body weight, the body height and thus, the BMI. No obvious correlation between the cranial capacity and the neuromuscular functions was observed, although careful interpretation is called.

\section{ACKNOWLEDGEMENTS}

Thank you to all colleagues in The Department of Anatomy and Histology, Faculty of Medicine, Universitas Airlangga, Surabaya, Indonesia for the assistance given during the study. Thank to Prof. Macie Henneberg (The University of Adelaide, Australia) for the guidance.

KALANJATI, V. P. Estimación de capacidad cranial e indicadores de crecimiento en niños de educación primaria. Int. J. Morphol., 32(1):7-11, 2014.

RESUMEN: La capacidad craneal (CC) se puede utilizar para estimar el volumen del cerebro y correlacionarlo con el crecimiento y desarrollo de los niños. La antropometría es un método útil para obtener datos de la capacidad craneal estimada y otros indicadores de crecimiento, incluyendo el peso corporal (PC) y la altura del cuerpo (AC). La prueba del reflejo neuromuscular 
(PRNM) es un método para observar la función neuromuscular de los niños. El objetivo de este trabajo fue estudiar la correlación entre CC estimada, PC, AC,índice de masa corporal (IMC) y la función neuromuscular en niños de educación primaria entre 7 y 14 años de edad, en el Este de Java, Indonesia. El estudio antropométrico se realizó en 153 niños y 145 niñas de 3 escuelas primarias de Java Oriental para medir PC, AC y calcular el IMC por la fórmula OMS. Con el objetivo de calcular CC utilizando la fórmula de Manjunath (2002a), se registraron datos incluyendo el PRNM y longitud de la cabeza, el ancho máximo de la cabeza entre las eminencias parietales, como también la altura de la cabeza al vértice al tragus. Las correlaciones entre la CC, PC, AC, IMC y PRNM se analizaron con Microsoft Excel. Para la comparación de la capacidad craneal entre niños y niñas, se realizó la prueba t de dos colas ( $p>0,05)$. En los niños encontramos una correlación positiva entre la CC y el IMC ( $\mathrm{r}=0,38), \mathrm{PC}(\mathrm{r}=0,4), \mathrm{AC}(\mathrm{r}=0,3)$; mientras que no se observó ninguna correlación obvia entre la CC y PRNM $(\mathrm{r}=0,07)$. En las niñas se observó una correlación positiva entre la CC y el IMC $(r=0,33), P C(r=0,45)$ y AC $(r=0,48)$; mientras que se observó una correlación negativa entre la CC y PRNM $(\mathrm{r}=-0,05)$. Los resultados indican que hay una fuerte correlación lineal entre $\mathrm{CC}$ e IMC, y entre PC y AC en los niños y niñas. No se encontraron correlaciones evidentes entre CC y PRNM en niños y niñas.

PALABRAS CLAVE: Craneometría; Morfología; Desarrollo humano.

\section{REFERENCES}

Acer, N.; Usanmaz, M.; Tugay, U. \& Erteki'n, T. Estimation of cranial capacity in 17-26 years old university students. Int. J. Morphol., 25(1):65-70, 2007.

Dekaban, A. S. Tables of cranial and orbital measurements, cranial volume and derived indices in males and female from 7 days to 20 yrs of age. Ann. Neurol., 2(6):485-9, 1977.

Gault, D.; Brunelle, F.; Renier, D. \& Marchac, D. The calculation of intracranial volume using CT scans. Childs Nerv. Syst., 4(5):271-3, 1988.

Hwang, Y. I.; Lee, K. H; Choi, B. Y.; Lee, K. S.; Lee, H. Y.; Sir, W. S.; Kim, H. J.; Koh, K. S.; Han, S. H. \& Chung, M. S. Study on the Korean adult cranial capacity. J. Korean Med. Sci., 10(4):239-42, 1995.

Johnson, F. W. Biological factors and psychometric intelligence: a review. Genet. Soc. Gen. Psychol. Monogr., 117(3):313-57, 1991.

MacKinnon, I. L. The relation of the capacity of the human skull to its roentgenological length. Am. J. Roentgenol. Radium Ther. Nucl. Med., 14(6):1026-9, 1955.

Manjunath, K. Y. Estimation of cranial volume-an overview of methodologies. J. Anat. Soc. India, 51(1):85-91, 2002a.
Manjunath, K. Y. Estimation of cranial volume in dissecting room cadavers. J. Anat. Soc. India., 51(2):168-72, 2002 b.

Mazonakis, M.; Karampekios, S.; Damilakis, J.; Voloudaki, A. \& Gourtsoyiannis, N. Stereological estimation of total intracranial volume on CT images. Eur. Radiol., 14(7):1285-90, 2004.

Pearl, R. Biometrical studies on man. I. Variation and correlation in brain-weight. Biometrika, 4:13-104, 1995.

Piatt, J. H. Jr. \& Arguelles, J. H. Reduction cranioplasty for craniocerebral disproportion in infancy: indications and technique. Pediatr. Neurosurg., 16(4-5):265-70, 1991.

Sgouros, S.; Goldin, J. H. \& Hockley, A. D. Intracranial volume change in childhood. J. Neurosurg., 91(4):610-6, 1999.

Ward, M. A.; Carlsson, C. M.; Trivedi, M. A.; Sager, M. A. \& Johnson, S. C. The effect of body mass index on global brain volume in middle-aged adults: a cross sectional study. $B M C$ Neurol., 5(1):23, 2005.

Witelson, S. F.; Beresh, H. \& Kigar, D. L. Intelligence and brain size of 100 postmortem brains: sex, lateralization and age factors. Brain, 129(Pt. 2):386-98, 2006.

Wolf, H.; Kruggel, F.; Hensel, A.; Wahlund, L. O.; Arendt, T. \& Gertz, H. J. The relationship between head size and intracranial volume in elderly subjects. Brain Res., 973(1):74-80, 2003.

\section{Correspondence to: \\ Viskasari P. Kalanjati \\ Department of Anatomy and Histology \\ Faculty of Medicine Universitas Airlangga \\ Surabaya \\ INDONESIA}

Email: viskasari-p-k@fk.unair.ac.id

Received: 23-09-2013

Accepted: 17-11-2013 